\title{
IMPLEMENTASI MODEL PEMBELAJARAN BERBASIS MASALAH LOKAL DALAM MENGEMBANGKAN KOMPETENSI EKOLOGIS PADA PEMBELAJARAN IPS
}

\author{
Muhaimin \\ SDN Aengtabar 1 Tanjungbumi Bangkalan Madura \\ Email:muhaimin_mafandi@yahoo.co.id \\ Naskah diterima : 1 April 2015, direvisi : 5 Mei 2015, disetujui : 25 Mei 2015
}

\begin{abstract}
Human and the environment is an integrated system to form ecosystems in which humans are physically and socially dependent. One concern is the content of social studies related to the ecological interactions between humans and the environment. In the factual context, ecological competence developed in social studies only at the level of knowlegde ecological, moral, and behavior, which has not been valued and embodied in the form of concrete to protect and sustain the environment. The results showed no differences in ecological competence for aspects of knowledge, attitudes, and skills between the pre-test and post-test. The study recommends that the implementation of learning social science education in a broader scope based on local environmental issues are found in everyday life. Schools cultivate ecological competence through the formation of habits, role modeling, and school behavior and culture form a joint motion which is in line with the curriculum green and green living.
\end{abstract}

Keywords: local environmental issues; ecological competence; social science education

\begin{abstract}
Abstrak
Manusia dan lingkungan adalah sistem yang terpadu membentuk ekosistem di mana manusia secara fisik dan sosial tergantung. Salah satu perhatian dari studi sosial adalah konten ekologi yang berkaitan dengan interaksi antara manusia dan lingkungannya. Dalam konteks faktual, kompetensi ekologi yang dikembangkan dalam studi sosial hanya pada tingkat knowlegde ekologi, moral, dan perilaku, yang belum dihargai dan diwujudkan dalam bentuk konkrit untuk melindungi dan mempertahankan lingkungan. Hasil penelitian menunjukkan ada perbedaan kompetensi ekologi untuk aspek pengetahuan, sikap, dan keterampilan antara pra-test dan post-test. Penelitian ini merekomendasikan bahwa pelaksanaan pembelajaran Ilmu Pengetahuan Sosial pada lingkup yang lebih luas berdasarkan pada isu-isu lingkungan setempat yang ditemukan dalam kehidupan sehari-hari. Sekolah menumbuhkan kompetensi ekologi melalui pembentukan kebiasaan, pemodelan peran, dan perilaku sekolah membentuk gerakan sendi dan budaya yang sejalan dengan kurikulum hijau dan hidup hijau.
\end{abstract}

Kata kunci: isu lingkungan lokal; kompetensi ekologi; Ilmu Pengetahuan Sosial

Pengutipan: Muhaimin. (2015). Implementasi Model Pembelajaran Berbasis Masalah Lokal dalam Mengembangkan Kompetensi Ekologis pada Pembelajaran IPS. SOSIO DIDAKTIKA: Social Science Education Journal, 2(1), 2015, 12-21. doi:10.15408/sd.v2i1.1409

Permalink/DOI: http://dx.doi.org/10.15408/sd.v2i1.1409 


\section{A. Pendahuluan}

Manusia dan lingkungan merupakan sistem yang integral dalam membentuk ekosistem. Manusia sangat tergantung terhadap lingkungan hidupnya, baik lingkungan fisik dan sosial. Pentingnya menjaga dan melestarikan lingkungan merupakan tanggung jawab bersama masyarakat dunia. Seperti yang dinyatakan Ward \& Dubos bahwa bumi hanyalah satu (only one earth) yang kelangsungan hidupnya sangat tergantung kepada manusia untuk menjaga dan melestarikan lingkungan. ${ }^{1}$

Kesadaran bumi sebagai satu-satunya planet tempat tinggal manusia dengan segala potensi dan sekaligus keterbatasannya dalam menopang keberlanjutan hidup manusia, perlu dikembangkan dalam komitmen bersama. Sebagai sebuah ekosistem global, bumi dibentuk dan dipengaruhi oleh sistem-sistem yang lebih kecil termasuk cara pandang manusia secara individual dalam memahami ruang di mana ia tinggal (act locally). Maryani menyatakan bahwa manusia dan juga ruang secara mikro/ individual memiliki karakter, jati diri, dan brand image sebagai sebuah produk dari interaksi lingkungan fisik, sosial, dan budaya. Dalam diri manusia, persepsi tentang ruang diproses melalui keterampilan berpikir dan diwujudkan dalam perilaku keruangan. ${ }^{2}$

Berbagai permasalahan lingkungan seperti: pemanasan global, penipisan lapisan ozon, hujan asam, perubahan iklim yang tidak menentu, kerusakan lingkungan, krisis sumber daya alam, pencemaran lingkungan, desertifikasi, penurunan keanekaragaman hayati, kebakaran hutan, deforestasi, kekeringan, banjir, erosi, intrusi air laut, dan sebagainya yang terjadi dalam skala lokal, nasional dan global merupakan permasalahan bersama yang harus ditanggulangi secara kolektif. ${ }^{3}$ Dalam konteks pendidikan, siswa perlu disiapkan untuk menyikapi berbagai krisis ekologi dengan membentuk sikap dan kepedulian sebagai bentuk dari tanggung jawab manusia untuk masa depan bersama dan

\footnotetext{
1 Ward, B \& Dubos, R, Only One Earth. London: Penguin (Paperback), 1972.

2 E. Maryani, "Pendidikan Geografi Sebagai Perekat Kebhinekaan Untuk Menuju Kesatuan Bangsa", dalam Peningkatan Kualitas Pendidikan Guru Menuju Asian Qualification Freamework, The $6^{\text {th }}$ International Conference of Teacher Education (UPI - UPSI), Bandung: UPI, 2014, h. 1.

3 J. A. Palmer \& Neil Philip, The Handbook of Environmental Education. London: Routledge, 1994, h. 57.
}

kehidupan yang berkelanjutan. ${ }^{4}$ Dalam konteks faktual, pada umumnya sikap dan kepedulian terhadap lingkungan belum terbentuk sepenuhnya dalam diri siswa. Siswa belum berperilaku sesuai dengan yang diharapkan dalam pendidikan lingkungan hidup. Indikasi dalam beberapa hal adalah masih banyaknya lingkungan sekolah yang kotor, partisipasi siswa dalam kegiatan lingkungan yang masih rendah, belum adanya kesadaran siswa dalam membentuk perilaku lingkungan, perilaku boros dalam dalam penggunaan sumber daya alam, apatis terhadap pelestarian lingkungan sekitar siswa, dan sebagainya.

Dalam pembelajaran IPS perlu dikembangkan model Problem Based Learning (PBL) yang menjadikan permasalahan lokal yang sesuai dengan karakteristik permasalahan lingkungan daerah yang bersangkutan. Model berbasis masalah lokal dilakukan dengan menganalisis masalah lingkungan hidup dalam konteks lokal sesuai dengan karakteristik ekologis dan sosial budaya masyarakat setempat. Pembelajaran diarahkan agar siswa dengan lingkungannya dapat beradaptasi sejak dini dan memanfaatkan lingkungan setempat yang tidak terbatas sebagai bahan dan sumber belajar.

Salahsatuperan penting dalam penyelamatan lingkungan adalah melalui pendidikan, yang dikenal dengan gerakan ecopedagogy. Gerakan ecopedagogy dan green curriculum berkembang dari pemikiran pedagogi kritis oleh filsuf Paulo Freire dan secara global merupakan kesadaran bersama untuk mewujudkan masyarakat yang mempunyai kepedulian dengan keseimbangan dan pelestarian lingkungan. ${ }^{5}$ Pedagogi kritis dipersepsikan sebagai realisasi dari teori kritis (critical theory) dari pemikir Frankefurt School yang diaplikasikan di sekolah. Pendidikan yang menaruh perhatian terhadap lingkungan hidup hadir sebagai bentuk dari eksploitasi manusia modern yang memanfaatkan lingkungan hidup secara berlebihan yang pada akhirnya merusak lingkungan hidup itu sendiri. Lahirlah pemikiran manusia, untuk mengkritisi berbagai permasalahan tersebut, dengan melahirkan konsep pendidikan yang mewujudkan masyarakat yang memiliki kepekaan dan

\footnotetext{
$4 \quad$ Sapriya. Pendidikan IPS. Bandung: Remaja Rosdakarya, 2011, h. 135 P. Freire, Pegagogy Pengharapan, Menghayati Kembali Pedagogi Kaum Tertindas. (terjemahan), Jakarta: Kanisius. 2005, h. 53.
} 
kepedulian terhadap pelestarian lingkungan hidup. $^{6}$

Lingkungan hidup dalam mata pelajaran IPS pada kurikulum terintegrasi dalam setiap struktur IPS. IPS dari kurikulum SD - SMP memuat secara khusus materi-materi yang berkenaan dengan lingkungan hidup. Materimateri tersebut dikembangkan dalam standar kompetensi dan kompetensi dasar dalam pembelajaran IPS. Kajian geografi, ekonomi, sosiologi, dan sejarah semuanya dapat diintegrasikan dengan kompetensi dan materi pendidikan lingkungan hidup.

Penelitian ini bertujuan untuk: (1) mengidentifikasi perbedaan kompetensi ekologis siswa aspek kognitif antara sebelum dan sesudah implementasi model berbasis masalah lokal, (2) mengidentifikasi perbedaan kompetensi ekologis siswa aspek kognitif antara sebelum dan sesudah implementasi model berbasis masalah lokal; dan (3) mengidentifikasi perbedaan kompetensi ekologis siswa terutama dalam aspek keterampilan antara sebelum dan sesudah implementasi model berbasis masalah lokal.

\section{B. Metode Penelitian}

Rancangan penelitian ini adalah penelitian kuantitatif dengan pendekatan komparasi onegroup pratest-posttest design untuk membandingkan kompetensi ekologis yang terdiri dari aspek pengetahuan, sikap, dan keterampilan ekologis siswa antara sebelum dan sesudah implementasi model pembelajaran berbasis masalah lokal yang disesuaikan dengan kondisi masalah lingkungan dan kondisi geografis setempat. Ada efek perlakuan secara khusus yaitu implementasi model berbasis masalah lokal dalam pembelajaran sesuai dengan karakteristik permasalahan dan kondisi geografis masyarakat setempat.

Dalam penelitian ini variabel antara adalah model pembelajaran berbasis masalah lokal dan variabel sasaran adalah kompetensi ekologis siswa dalam mata pelajaran IPS. Kompetensi ekologis dikembangkan dalam pembelajaran IPS SD yang memiliki muatan ekologis, sesuai dengan

\footnotetext{
6 N. Supriatna, "Ecopedagogy dan Green Curriculum" dalam Pembelajaran Sejarah Pendidikan Sejarab Untuk. Manusia dan Kemanusiaan. Jakarta: Bee Media, 2012. h. 175.
}

Standar Kompetensi dan Kompetensi Dasar dalam kurikulum IPS. Kompetensi ekologis diartikan sebagai penguasaan pengetahuan, sikap atau nilai, dan keterampilan sehingga terbentuk kesadaran dan kepedulian terhadap pelestarian dan keseimbangan lingkungan hidup untuk mencari alternatif atau memberi solusi terhadap permasalahan lingkungan hidup yang ada sekarang dan menghindari timbulnya masalah-masalah lingkungan hidup baru, baik secara individu maupun kolektif.

Subjek penelitian adalah siswa kelas IV SDN Aengtabar 1 Kabupaten Bangkalan Jawa Timur Tahun Pelajaran 2014/2015, yang berjumlah 28 siswa dan seluruh subjek dijadikan sampel penelitian. Metode pengumpulan datanya menggunakan tes untuk pengetahuan ekologis, kuesioner untuk mengukur sikap, dan penilaian kinerja untuk mengetahui keterampilan ekologis. Analisis datanya menggunakan statistik uij paired samples $t$ test membandingkan nilai rata-rata pengetahuan, sikap, dan keterampilan ekologis sebelum dan sesudah implementasi model pembelajaran berbasis masalah lokal.

\section{Hasil Penelitian dan Pembahasan}

\section{Hasil Penelitian}

Berdasarkan hasil penelitian, diperoleh data: (1) pengetahuan tentang lingkungan hidup diperoleh nilai rata-rata sebelum implementasi model adalah 73,35, sedangkan sesudah implementasi model adalah 80,17 (2) sikap terhadap lingkungan hidup diperoleh nilai ratarata sebelum implementasi model adalah 73,50, sedangkan sesudah implementasi model adalah 79,78 dan (3) keterampilan lingkungan hidup diperoleh nilai rata-rata sebelum implementasi model adalah 71,00, sedangkan sesudah implementasi model adalah 73,57.

Berdasarkannilairata-ratatersebut,diketahui bahwa sesudah implementasi model berbasis masalah lokal, diperoleh nilai pengetahuan, sikap, dan keterampilan lingkungan hidup ratarata yang lebih tinggi dibandingkan dengan sebelum implementasi model berbasis masalah lokal. Secara keseluruhan kompetensi ekologis siswa dapat dideskripsikan dengan tabel 1 (hal.15). 
Uji asumsi dasar dengan menggunakan uji normalitas diperoleh hasil bahwa semua data berdistribusi normal, dan uji homogenitas menunjukkan kelompok data sampel berasal dari populasi yang memiliki varian yang sama. Hasil analisis data untuk membandingkan pengetahuan siswa tentang lingkungan hidup antara sebelum dan sesudah implementasi model berbasis masalah lokal yang diuji dengan menggunakan uji paired samples $t$ test diperoleh data yang dideskripsikan pada tabel 2 .

Hasil analisis data untuk membandingkan pengetahuan, sikap, dan keterampilan lingkungan hidup antara sebelum dan sesudah implementasi model yang diuji dengan menggunakan uji paired samples $t$ test menunjukkan ada perbedaan pengetahuan, sikap, dan keterampilan lingkungan hidup yang signifikan sebelum dan sesudah implementasi model berbasis masalah lokal.

Secara keseluruhan kompetensi ekologis aspek kognitif menunjukkan terjadinya peningkatan. Secara umum siswa menguasai isuisu ekologis yang berkaitan dengan pengetahuan tentang masalah-masalah lingkungan dalam kehidupan sehari-hari, penyebab permasalahan lingkungan, dampak permasalahan lingkungan, prediksi permasalahan lingkungan di masa yang akan datang, pengetahuan tentang solusi atau alternatif untuk menyelesaikan permasalahan lingkungan, dan pemahaman tentang ketergantungan manusia dan lingkungan serta saling ketergantungan individu, kelompok, komunitas, dan bangsa dalam pengelolaan lingkungan.

Selanjutnya siswa memahami dan mengetahui isu-isu permasalahan lingkungan hidup yang terjadi dalam konteks lingkungan masyarakatnya, memahami bahwa permasalahan lingkungan hidup masing-masing daerah berbeda sangat tergantung dengan karakteristik geografis setempat. Secara umum, siswa memahami bahwa isu-isu lingkungan hidup lokal yang dekat dengan kehidupan seharihari siswa, saat ini lebih menggugah kesadaran mereka untuk peduli dan berpartisipasi dalam kegiatan lingkungan hidup.

Mereka menyadari selama ini isu-isu lingkungan lebih banyak diarahkan pada isu-isu global, seperti: pemanasan global, menipisnya lapisan ozon, efek rumah kaca, dan sebagainya, sementara mereka melupakan permasalahan lingkungan di sekitarnya seperti: persoalan sampah, abrasi, kekeringan, penurunan daya dukung dan fungsi sungai, dan lain-lain. Hal inilah yang kemudian menggiring siswa untuk lebih banyak menggali dan memahami secara lebih mendalam apa dan bagaimana permasalahan lingkungan hidup di sekitarnya dengan mengkaji penyebab permasalahan lingkungan, dampak permasalahan lingkungan, prediksi permasalahan lingkungan di masa yang akan datang, pengetahuan tentang solusi atau alternatif untuk menyelesaikan permasalahan lingkungan tersebut yang semuanya memperkaya kemampuan ekologis siswa aspek pengetahuan.

Tabel 1

Perbandingan Kompetensi Ekologis

Sebelum dan Sesudah Implementasi Model Berbasis Masalah Lokal

\begin{tabular}{|c|c|c|c|c|c|}
\hline \multirow[t]{3}{*}{ No } & \multirow[t]{3}{*}{ Kompetensi Ekologis } & \multicolumn{2}{|c|}{ Nilai Rata-rata } & \multirow[t]{3}{*}{ Gain } & \multirow[t]{3}{*}{ N-Gain } \\
\hline & & Sebelum Perlakuan & Sesudah & & \\
\hline & & & Perlakuan & & \\
\hline 1. & Pengetahuan & 73.35 & 80.17 & 6,82 & 0,255 \\
\hline 2. & Sikap & 73,50 & 79,78 & 6,28 & 0,236 \\
\hline 3. & Keterampilan & 71,00 & 73,57 & 2,57 & 0,088 \\
\hline
\end{tabular}

Tabel 2

Ringkasan Uji Statistik

\begin{tabular}{llll}
\hline No & Kompetensi Ekologis & Signifikansi & Keterangan \\
\hline 1. & Pengetahuan & $0,000>0,05$ & Ada Perbedaan \\
2. & Sikap & $0,000>0,05$ & Ada Perbedaan \\
3. & Keterampilan & $0,000>0,05$ & Ada Perbedaan \\
\hline
\end{tabular}


Dalam kompetensi ekologis aspek sikap secara keseluruhan dalam implementasi model sudah mulai terbentuk. Terdapat peningkatan kompetensi ekologis siswa pada aspek sikap sebelum dan sesudah perlakuan. Bagaimana siswa merespon permasalahan lingkungan dengan menunjukkan jati diri tentang apa dan bagaimana seharusnya dilakukan oleh siswa. Selain itu pemikiran siswa terhadap isuisu lingkungan juga lebih baik. Apresiasi dan kepedulian terhadap lingkungan pada umumnya sudah tumbuh dalam diri siswa, menghargai pendapat dan pandangan orang lain, bukti dan argumentasi yang logis terhadap permasalahan dan pengelolaan lingkungan, toleransi dan keterbukaan dalam pengelolaan lingkungan hidup, dan sebagainya. Siswa pada umumnya sudah mampu menyikapi bagaimana tindakan yang seharusnya dilakukan dalam usaha melestarikan dan bagaimana bersikap pada usaha dan tindakan yang merusak terhadap lingkungan hidup.

Secara keseluruhan, keterampilan ekologis siswa masih terbatas pada ruang lingkup sekolah. Aktivitasnya pun belum banyak dilakukan oleh siswa, terbatas pada kegiatan-kegiatan mendasar seperti: menjaga kebersihan kelas dan sekolah, membuang sampah pada tempatnya, melakukan pemilahan sampah, melakukan pengelolaan sampah, mendaur ulang sampah, menjaga kebersihan toilet dan menggunakan air secukupnya, menghemat listrik, menggunakan kertas secara bijaksana, melakukan penghijauan di sekolah dan sebagainya. Keterampilan ekologis praktis dalam lingkup yang lebih luas perlu ditingkatkan secara keseluruhan.

Keterampilan menggunakan dan memanfaatkan sumber daya secara bijaksana, masih belum banyak dilakukan oleh siswa dalam kehidupan sehari-hari. Pada umumnya siswa menyadari bahwa hal itu sangat penting dilakukan, tetapi kurang diimplementasikan dalam tindakan nyata dalam bentuk perilaku. Menggunakan air secara bijaksana sesuai dengan keperluan dan menghemat listrik sudah mulai dilakukan oleh sebagian besar siswa, tetapi melakukan penghematan energi minyak dengan menggunakan energi alternatif dalam kehidupan sehari-hari, menggunakan bahan bakar minyak sesuai dengan kebutuhan masih sangat jarang dilakukan oleh siswa.

Melakukan penghematan dalam pemakaian kertas dengan menggunakannya sesuai keperluan masih belum banyak siswa yang melakukannya. Siswa sangat akrab dengan kertas, karena digunakan dalam kegiatan pembelajaran di sekolah, tetapi mereka pada umumnya belum bisa menghemat kertas. Indikatornya adalah rata-rata pemakaian buku yang banyak, boros dengan membuang kertas, dan sangat tergantung dengan kertas dalam pembelajaran.

Keterampilan ekologis dalam perilaku membuang sampah pada tempat yang disediakan pada umumnya sebagian besar siswa sudah melakukannya, meskipun terdapat beberapa tempat dalam lingkungan sekolah yang masih kotor dengan sampah. Melakukan pemilahan dalam membuang sampah antara sampah organik dan non-organik serta sampah kering dan sampah basah belum banyak dilakukan oleh siswa. Sangat jarang siswa yang terlibat dalam proses pengelolaan sampah seperti melakukan penimbunan terhadap sampah-sampah yang tidak mudah terurai seperti kaleng dan plastik, memanfaatkan sampah hijau untuk pupuk kompos, melakukan penimbunan terhadap limbah atau sampah yang berbahaya, seperti obat-obatan yang tidak terpakai dan limbah berbahaya lainnya. Dalam konteks sekolah mereka menyerahkan sepenuhnya pengelolaan sampah kepada petugas kebersihan sekolah, dan pengelolaan sampah oleh petugas kebersihan juga kurang dikelola dengan baik.

Aktivitas keterampilan ekologis siswa masih terbatas pada ruang lingkup sekolah. Aktivitasnya pun belum banyak dilakukan oleh siswa, terbatas pada kegiatan-kegiatan mendasar seperti: menjaga kebersihan kelas dan sekolah, membuang sampah pada tempatnya, menjaga kebersihan toilet dan menggunakan air secukupnya, dan sebagainya. Secara umum tingkat keterlibatan siswa secara aktif dalam gerakan lingkungan hidup baik di sekolah maupun masyarakat masih tergolong sangat rendah. Hanya siswa yang aktif dalam komunitas lingkungan di sekolah yang mempunyai kompetensi partisipasi ekologis yang baik. Pada umumnya partisipasi dalam melakukan piket membersihkan kelas dan lingkungan 
sekolah secara keseluruhan baik. Tetapi tingkat keterlibatan siswa dalam pemilahan dan pembuangan sampah di sekolah, terlibat dalam kegiatan pengelolaan sampah organik menjadi pupuk kompos di sekolah, terlibat aktif dalam mengikuti kegiatan kerja bakti membersihkan lingkungan sekolah, menjadi wakil sekolah dalam kegiatan lingkungan di luar sekolah, terlibat dalam kegiatan penanaman pohon dan penghijauan di lingkungan sekolah masih sangat rendah.

\section{Pembahasan}

Temuan di lapangan menunjukkan bahwa terdapat peningkatan pengetahuan, sikap, dan keterampilan ekologis siswa dengan implementasi model berbasis masalah lokal yang sesuai dengan karakteristik geografis setempat. Lokalitas dalam konteks pembelajaran IPS menjadi sangat penting. Pembelajaran IPS harus berangkat dari isu-isu lokal, dengan mengkaji budaya lokal, kearifan lokal, fenomena lokal, dan sebagainya akan menentukan bagaimana pemahaman siswa terhadap lingkungan sosial masyarakatnya, sehingga dapat memainkan peran yang lebih menentukan dalam konteks kehidupan siswa sekarang dan di masa yang akan datang. Fenomena dan nilai-nilai lokal inilah yang memperkaya IPS itu sendiri.

Model berbasis masalah lokal memberikan pemahaman dan pengetahuan secara komprehensif bagi siswa untuk mengkaji berbagai permasalahan lingkungan hidup, dari memetakan masalah, menentukan prioritas masalah, melakukan penyelidikan lapangan, mendiskusikan hasil kerja kelompok, dan mengembangkan dan menyajikan hasil karya yang berhubungan dengan permasalahan lingkungan. Konsep-konsep belajar yang demikian, siswa belajar secara langsung dan menganalisis berbagai fakta, peristiwa, dan permasalahan sosial masyarakat siswa dapat membentuk kerangka berpikir logis dan kritis, rasa ingin tahu, inkuiri, memecahkan masalah, dan keterampilan kognitif lainnya.

Siswa aktif membangun pengetahuan, yang dilakukan berdasarkan apa yang telah diketahui siswa, dari proses awal sampai akhir pembelajaran. Kegiatan yang dilakukan sepenuhnya berada di tangan siswa sebagai subjek belajar. Oleh karena itu, hasil yang diperoleh lebih kompleks, lebih tahan lama, dan integral memahami permasalahan lingkungan. Interaksi antara siswa dengan lingkungan secara nyata melahirkan interaksi positif yang merangsang proses berpikir siswa.

Pengalaman siswa yang secara langsung diperoleh dari lingkungan menjadikan bahan dan materi untuk memperoleh pengetahuan serta dijadikan pedoman dan tujuan belajarnya. Pembelajaran dengan menganalisis permasalahan lingkungan hidup dalam konteks lokal menjadikan pembelajaran lebih bermakna bagi siswa. Pembelajaran yang bermakna merupakan pembelajaran yang menghubungkan fenomena dan pengalaman baru ke dalam struktur pengetahuan yang sudah dimiliki seseorang dalam belajar, menemukan secara aktif dalam pembelajarannya, memberikan hasil yang lebih baik dalam pembelajaran.

Lokalitas juga memberikan masalah esensial dan aktual tentang permasalahan lingkungan. Dalam konteks ini siswa memahami secara lebih jelas masalah yang akan dikaji, karena terjadi dalam lingkungannya dan dekat baik secara geografis maupun psikologis. Dalam konteks lokal inilah pembelajaran IPS muatan ekologis dapat menjembatani kesenjangan pemahaman dan kesadarannya tentang permasalahan lingkungan hidup di sekitar lingkungan siswa. ${ }^{7}$

Orisinalitas dan kekhasan masing-masing daerah berbeda. Siswa mengamati, memahami, menganalisis, dan menginterpretasi segenap fenomena dan sumber daya dalam lingkungan sekitarnya. Dalam hal ini juga setiap masyarakat memiliki cara tersendiri dalam menyikapi dan memperlakukan lingkungannya. Hasil penelitian tentang fenomena siswa yang memiliki tingkat kontrol atau pengawasan yang rendah tentang lingkungan di sekitarnya dan kurang memiliki kepedulian terhadap isu-isu lokal lingkungan dibandingkan dengan isu-isu global, ${ }^{8}$ dapat diatasi dengan mendekatkan siswa terhadap persoalan-persoalan hidup lokal dalam lingkungan masayarakatnya. Lokalitas memiliki kedekatan secara emosional kepada siswa dan memiliki ikatan kolektivitas yang kuat pada diri

\footnotetext{
S. Hamzah, Pendidikan Lingkungan Hidup, Sekelumit Wawasan Pengantar, Bandung: Refika Aditama, 2013, h. 51

J. Ai Fien, D. Yencken, H. Sykes, and D. Treagust, "Youth Environmental Attitudes in Australia and Brunei: Implications for Education", The Environmentalist, 22, 205-216, 2002, p. 205-216.
} 
seseorang, sehingga akan memberikan motivasi yang lebih kuat kepada siswa untuk memiliki kepedulian yang kuat terhadap lingkungan.

Muatan materi yang bersumber dari realitas dan fenomena lokal dapat mempermudah pemahaman siswa dan efektif meningkatkan kompetensi ekologis yang diharapkan. Bahan pembelajaran yang sesuai dengan kebutuhan daerah dapat mengembangkan minat siswa dalam pembelajaran. ${ }^{9}$ Selain itu dapat mengeksplorasi fenomena dan kearifan lokal dapat membentuk perilaku yang selaras dengan lingkungan hidup. ${ }^{10}$

Pembentukan sikap dan keterampilan ekologis siswa berproses dan terasah dengan baik ketika dihadirkan permasalahanpermasalahan lingkungan hidup, terutama yang terjadi di lingkungan sekitarnya. Dampak dan akibat yang ditimbulkan dari permasalahan tersebut, menggugah siswa untuk memiliki sikap yang positif terhadap lingkungan. Sikap inilah yang kemudian membentuk konsep diri yang positif bagi siswa dalam memandang diri dan lingkungannya. Sikap inilah yang memberikan gambaran bagaimana siswa merespon dan berperilaku sesuai dengan prinsip-prinsip ekologis.

Sikap pada dasarnya merupakan kontrol diri dalam diri seseorang. Kontrol yang berasal dari dalam diri seseorang adalah lebih sehat daripada kontrol yang dipaksakan dan berasal dari luar. Dari itulah sikap yang baik seseorang akan menentukan respon dan perilaku seseorang dalam menghadapi berbagai hal. ${ }^{11}$ Sehingga kemudian, sikap dan keterampilan ekologis siswa dapat tumbuh dan berkembang sesuai dengan kapasitas yang ingin dicapai.

Permasalahan lingkungan hidup memberikan landasan kepada siswa untuk menyikapi dan merespon dengan positif. Sikap inilah yang akan menuntun siswa untuk memiliki moral ekologis, yang memberikan gambaran tentang diri yang sesuai dengan kenyataan dirinya (real self). Sikap bukanlah suatu bentuk yang statis, melainkan selalu berkembang secara

\footnotetext{
9 S. Hamzah, Pengembangan Model Baban Ajar Pendidikan Lingkungan Hidup Berbasis Lokal Dalam Mata Pelajaran Ilmu Pengetabuan Sosial. FKIP Universitas Bengkulu. 2007.

289.

10 S. Keraf, Etika Lingkungan, Jakarta: Penerbit Buku Kompas, 2002, h. H. Friedman \& M.W. S
Modern, Jakarta: Erlangga, 2008, h. 343.
}

dinamis dan dipengaruhi oleh berbagai faktor. Untuk itulah sikap yang berkenaan dengan moralitas lingkungan perlu dibentuk secara terus-menerus sehingga terbentuk kesadaran dan kepedulian terhadap lingkungan.

Kemampuan dalam memahami isuisu lingkungan dari berbagai sudut pandang membuat siswa memiliki kemampuan yang komprehensif dalam mengkaji permasalahan lingkungan. Menganalisis faktor penyebab, dampak, dan solusi dari berbagai perspektif kajian, membuat siswa memiliki pemahaman yang utuh, sehingga siswa memiliki nalar yang saling berkaiatan antara berbagai aspek kehidupan lainnya. Contoh sederhana ketika siswa berbicara masalah abrasi, faktor penyebab, dampak, dan solusi dari permasalahan abrasi dikaji dalam perspektif ekonomi, sejarah, sosial, budaya, geografi, dan sebagainya. Hal ini sangat membantu siswa dalam pengambilan keputusan dan tindakan positif dalam merespon kondisi lingkungan yang dihadapi yang relevan dengan kondisi masyarakat yang bersangkutan.

Secara umum tingkat keterlibatan siswa dalam secara aktif dalam gerakan lingkungan hidup baik di sekolah maupun masyarakat masih tergolong sangat rendah. Secara keseluruhan hanya siswa yang aktif dalam komunitas lingkungan di sekolah yang mempunyai kompetensi partisipasi ekologis yang baik. Pada umumnya partisipasi dalam melakukan piket membersihkan kelas dan lingkungan sekolah secara keseluruhan baik, tetapi tingkat keterlibatan siswa dalam pemilahan dan pembuangan sampah di sekolah, terlibat dalam kegiatan pengelolaan sampah organik menjadi pupuk kompos di sekolah, terlibat aktif dalam mengikuti kegiatan kerja bakti membersihkan lingkungan sekolah, menjadi wakil sekolah dalam kegiatan lingkungan di luar sekolah, terlibat dalam kegiatan penanaman pohon dan penghijauan di lingkungan sekolah masih sangat rendah.

Dalam tataran keterlibatan siswa dalam bagian dari kelompok pembuat kebijakan lingkungan hidup baik di sekolah maupun masyarakat secara keseluruhan sangat rendah. Memberikan ide dan gagasan dalam pengelolaan lingkungan hidup dalam tataran kelas dan 
sekolah masih sangat jarang dilakukan oleh siswa. Selain itu pada umumnya siswa belum melakukan tindakan untuk menggerakkan teman dan lingkungan terdekat untuk memiliki kepedulian dan partisipasi terhadap lingkungan. Keterlibatan siswa dalam pengawasan kelestarian lingkungan hidup dengan melakukan diskusi membahas, mengkritisi dengan teman sekolah dan kelompok masyarakat mengenai permasalahan lingkungan hidup di sekitarnya masih sangat jarang dilakukan oleh siswa. Mengkomunikasikan berbagai ide dan gagasan dalam menyelesaikan permasalahan lingkungan hidup, bekerja sama dengan organisasi atau kelompok masyarakat dalam usaha pelestarian lingkungan hidup, dan kesedian meluangkan untuk waktu dan tenaga untuk membahas kegiatan lingkungan hidup di sekolah masih sedikit siswa yang bersedia melakukannya, hanya terbatas pada aktivitis lingkungan di sekolah yang jumlahnya masih sangat terbatas.

Pada umumya siswa terlibat dalam kegiatan ekstrakurikuler yang konsen terhadap lingkungan hidup, seperti pramuka, kebun sekolah, dan lain-lain. Siswa yang mengikuti kegiatan ekstrakurikuler dalam penelitian pada umumnya memiliki keterampilan ekologis yang lebih baik dibandingkan dengan siswa yang tidak mengikuti kegiatan ekstrakurikuler yang mendukung terhadap pelestarian lingkungan. Tetapikegiatan lingkungan hidup mendapat porsi yang lebih sedikit dibandingkan dengan kegiatan lainnya. Aktivitas kegiatan ekstrakurikuler yang menaruh perhatian terhadap lingkungan dilakukan tidak begitu banyak dan kurang terprogram dengan baik. Keterlibatan siswa dalam kegiatan ekstrakurikuler berkontribusi positif dalam meningkatkan partisipasi ekologis siswa secara keseluruhan. ${ }^{12} \mathrm{Hal}$ ini diperkuat oleh hasil-hasil penelitian sebelumnya bahwa kegiatan pramuka, organisasi komunitas, aksi kepemudaan, dan sebagainya efektif meningkatkan partisipasi generasi muda terhadap pelestarian lingkungan. ${ }^{13}$

Dengan implementasi model berbasis

12 R. Dewi, "Studi Kasus Pengetahuan, dan Kepedulian terhadap Lingkungan Hidup", dalam Jurnal Damianus, Vol 8 No. 2, Fakultas Kedokteran Unika Atma Jaya Jakarta, Mei 2009, h. 112-124.

13 T. Schusler dan M. E. Krasny, "Environmental Action as Contex for Youth Development", The Journal of Environmental Education, 41 (4), pp. 208 223. Lihat pula, B. Bruyere, M. Wesson, T. Teel, "Incorporating Environmental Education into an Urban After-School Program in New York City", International Journal of Environmental \& Science Education, Vol. 7, No. 2, April 2012, p. 327-341. masalah lokal dalam kehidupan siswa sekarang dan di masa yang akan datang tumbuh dan berkembang pemikiran untuk mengkritisi berbagai permasalahan tersebut, dengan mewujudkan masyarakat memiliki kepekaan dan kepedulian terhadap pelestarian lingkungan hidup. Hal inilah yang akan menjadi bekal bagi siswa dalam kehidupan di masa yang akan datang dengan mewujudkan berbagai kehidupan yang berkeadilan terutama dalam keseimbangan dan pelestarian lingkungan hidup.

Implementasi model berbasis masalah lokal dalam proses dan hasilnya menjadikan IPS lebih scientific. Kondisi ini sekaligus memperkuat epistimologis IPS dalam konteks pendidikan di sekolah. Kelemahan mendasar IPS selama ini terletak pada proses belajar, proses belajar menjadi lemah dan terperangkap kepada proses menghafal hanya menyentuh pengembangan kognitif tingkat rendah. Proses belajar belum mengembangkan kemampuan berpikir tingkat tinggi. Pentingnya IPS dirancang untuk meningkatkan kesadaran siswa tentang masalah-masalah sosial dan melibatkannya untuk memecahkan masalah-masalah dalam kehidupan sosialnya dengan menggunakan langkah-langkah berpikir reflektif dan eksplorasi data secara empiris dalam rangka menumbuhkan sikap ilmiah. ${ }^{14}$

Siswa antusias melakukan investigasi lapangan dengan menganalisis deskripsi permasalahan lingkungan, bentuk-bentuk kerusakan, faktor penyebab permasalahan lingkungan hidup, dan solusi permasalahan lingkungan hidup. Siswa bekerja secara berkelompok dalam mengobservasi, menganalisis, mengambil keputusan, membuat solusi, dan mengembangkan kemampuan bekerja sama dengan orang lain. Siswa mengeksplorasi berbagai isu atau permasalahan lingkungan dalam masyarakat dengan tujuan menganalisis berbagai isu atau permasalahan dalam masyarakat yang kemudian menjadi dasar siswa untuk mencari dan menemukan solusi atas berbagai permasalahan lingkungan hidup tersebut.

Investigasi lapangan dalam implementasi model berbasis masalah lokal yang dilakukan mampu memunculkan banyak temuan

14 P. Eggen, dan D. Kauchak, Strategic and Models for Teacher: Teaching Content and Thinking Skills. Sixth Edition. Boston: Pearson Education, 2012. 
lapangan yang lebih kompleks, sesuai dengan fakta yang terjadi di lapangan yang mereka temukan. Seperti halnya abrasi, mereka (siswa) menemukan pemecah gelombang, tanggul dan sebagainya untuk mengurangi gelombang air laut yang efektif menahan derasnya abrasi. Ketika berbicara mengenai permasalahan terumbu karang siswa menemukan berbagai jenis jaring, alat tangkap nelayan yang merusak terumbu karang. Jaring tertentu yang menangkap ikan seperti udang dan kerang-kerangan yang hidup di dasar laut dapat merusak terumbu karang. Temuan-temuan di lapangan inilah yang membuat analisis permasalahan menjadi lebih tajam dan kompleks, memunculkan hal-hal yang dapat memperkaya pengetahuan siswa terhadap berbagai fenomena dan fakta yang memperkuat dalam mengkaji permasalahan lingkungan hidup.

Hal-hal praktis dari kehidupan sehari-hari harus dimasukkan dalam pembelajaran sehingga terbentuk keterampilan dan partisipasi aktif dalam pengelolaan lingkungan hidup. Materi dan metode pelaksanaan pendidikan lingkungan hidup tidak aplikatif, kurang mendukung penyelesaian permasalahan lingkungan hidup yang dihadapi di daerah masing-masing.

Model berbasis masalah lingkungan hidup lokal mengkritisi permasalahan lingkungan hidup dalam masyarakat akan memperkaya IPS itu sendiri. Pendidikan IPS akan stagnan jika tidak dikritisi dengan berbagai hal yang berhubungan dengan rekontruksi sosial masyarakat yang berkembang dengan berbagai fenomenanya, termasuk isu-isu tentang lingkungan hidup. Isu-isu global yang harus direspon dalam pendidikan IPS dan bidangbidang lain yang digali dari kehidupan praktis sehari-hari di masyarakat. Materi inilah yang menjadi bagian dari kritisi dalam pembelajaran IPS, sehingga menjadi lebih bernyawa.

\section{Penutup}

Model pembelajaran berbasis masalah lokal efektif meningkatkan kompetensi ekologis siswa. Ada perbedaan yang signifikan pengetahuan, sikap, dan keterampilan lingkungan hidup sebelum dan sesudah implementasi model berbasis masalah lokal.
Lokalitas juga memberikan masalah esensial dan aktual tentang permasalahan lingkungan. Dalam konteks ini siswa memahami secara lebih jelas masalah yang akan dikaji, karena terjadi dalam lingkungannya dan dekat baik secara geografis maupun psikologis. Muatan materi yang bersumber dari realitas dan fenomena lokal dapat mempermudah pemahaman siswa dan efektif meningkatkan kompetensi ekologis yang diharapkan. Penelitian ini merekomendasikan secara lebih luas implementasi model berbasis masalah yang berangkat dengan isu-isu lokal dari permasalahan lingkungan dalam kehidupan sehari-hari. Sekolah perlu menumbuhkan kompetensi ekologis dengan pembiasaan (babit formation), memberikan keteladanan (role model), dan gerakan bersama yang membentuk perilaku dan budaya sekolah yang selaras dengan green curriculum dan green living.

\section{E. Daftar Pustaka}

Barr, R, Barth, J.L, Shermis, S.S. (1978). The Nature of Social Studies. California, Palm Spring: ETC Publications.

Capra, F. (2005). Ecological Literacy: Educating Our Children for a Sustainable World. Edited by Michael K. Stone \& Zenobia Barlow. San Fransisco: Sierra Club Books.

Dewey, J. (1916). Democracy and Education: An Introduction to the Philosophy of Education. New York: The Macmillan Company.

Dewi, R. (2009). Studi Kasus Pengetahuan, dan Kepedulian terhadap Lingkungan Hidup. Fakultas Kedokteran Unika Atma Jaya Jakarta. Jurnal Damianus Vol 8 No. 2 Mei 2009.

Eggen, P dan Kauchak, D. (2012). Strategic and Models for Teacher: Teaching Content and Thinking Skills. Sixth Edition. Boston: Pearson Education.

Fien, J, Ai, Yencken, D, Sykes, H and Treagust, D. (2002). Youth Environmental Attitudes in Australia and Brunei: Implications for Education. The Environmentalist, 22, 205-216, 2002. 
Freire, P. (2005). Pegagogy Pengharapan, Menghayati Kembali Pedagogi Kaum Tertindas. (terjemahan). Jakarta: Kanisius.

Friedman, H \& Schustack, MW. (2008). Kepribadian Teori Klasik dan Riset Modern. Jakarta: Erlangga.

Goleman, D. (2010). Kecerdasan Ekologis: Mengungkap Rahasia di Balik ProdukProduk yang Kita Beli. Jakarta: Gramedia.

Goleman, D, Bennet, L, \& Barlow, Z. (2012). Eco Literacy. San Fransisco: Jossey-Bass Published.

Gyallay, P. Environment: PAP-ETAP Reference Guide Book, Chapter 13. 2004 (http// www.un.org.kh/fae/pdfs/ section4/ chapterxxx3/33.pdf). (28 Agustus 2012).

Hamzah, S. (2007). Pengembangan Model Bahan Ajar Pendidikan Lingkungan Hidup Berbasis Lokal Dalam Mata Pelajaran Ilmu Pengetahuan Sosial. FKIP Universitas Bengkulu.

Hamzah, S. (2013). Pendidikan Lingkungan Hidup, Sekelumit Wawasan Pengantar. Bandung: Refika Aditama.

Hill, A. (2013). The Place of Experience and the Experience of Place: Intersections Between Sustainability Education and Outdoor Learning. Australian Journal of Environmental Education Volume 29(1) July 2013.

Hurlock, E. B.(2008). Child Development. Alih Bahasa Dr. Med. Meitasari Tjandrasa. Jakarta: Erlangga.

Kementerian Lingkungan Hidup. (2004). Kebijakan Pendidikan Lingkungan Hidup. Jakarta: Kementerian Lingkungan Hidup.
Keraf, S. (2002). Etika Lingkungan. Jakarta: Penerbit Buku Kompas.

Kilınc, A. (2010). Can Project-Based Learning Close The Gap? Turkish Student Teachers And Proenvironmental Behaviours. International Journal of Environmental \& Science Education Vol. 5, (4) October 2010.

Maryani, E. (2014). Pendidikan Geografi Sebagai Perekat Kebbinekaan Untuk Menuju Kesatuan Bangsa dalam Peningkatan Kualitas Pendidikan Guru Menuju Asian Qualification Freamework. The $6^{\text {th }}$ International Conference of Teacher Education (UPI - UPSI). Bandung: Universitas Pendidikan Indonesdia.

Palmer, J. A. (1998). Environmental Education in the 21st Century: Theory, Practice, Progress and Promise. London: Routledge.

Palmer, J. A \& Phlip, N (1994). The Handbook of Environmental Education. London: Routledge.

Sanjaya, W. (2006). Strategi Pembelajaran Berorientasi Standar Proses Pendidikan. Jakarta: Kencana Prenada Media Group.

Sapriya. (2011). Pendidikan IPS. Bandung: Remaja Rosdakarya.

Schusler, T dan Krasny M. E. (2010). Environmental Action as Context for Youth Development. The Journal of Environmental Education, 41 (4).

Supriatna, N. (2012). Ecopedagogy dan Green Curriculum dalam Pembelajaran Sejarah dalam Pendidikan Sejarah Untuk. Manusia dan Kemanusiaan. Editor: Hansiswany Kamarga dan Yani Kusmarini. Jakarta: Bee Media

Ward, B \& Dubos, R (1972). Only One Earth. London: Penguin (Paperback). 